\title{
TERRESTRIAL PASSERINES IN AN ATLANTIC FOREST REMNANT OF SOUTHERN BRAZIL
}

\author{
VOLPATO, G. H., ANJOS, L., POLETTO, F., SERAFINI, P. P., \\ LOPES, E. V. and FÁVARO, F. L. \\ Programa de Pós-Graduação em Ciências Biológicas, Departamento de Biologia Animal e Vegetal, \\ Universidade Estadual de Londrina, C. P. 6001, CEP 86051-970, Londrina, PR, Brazil \\ Correspondence to: Graziele Hernandes Volpato, Praça João da Costa Dias, 44, apto 101, \\ CEP 36570-000, Viçosa, Minas Gerais, Brazil, e-mail: gravolpato@yahoo.com.br \\ Received March 15, 2004 - Accepted July 6, 2004 - Distributed May 31, 2006
}

(With 2 figures)

\begin{abstract}
Microhabitats of four terrestrial passerines were studied in an Atlantic forest remnant of southern Brazil, in two areas (northern and southern) of the Mata dos Godoy State Park (PG). Grallaria varia and Hylopezus nattereri showed low abundance and occurred in only one PG area, while Chamaeza campanisona and Corythopis delalandi were recorded in two. The microhabitats of C. campanisona, G. varia, and H. nattereri had many large trees and a dense understory. Corythopis delalandi was in areas having few large trees.
\end{abstract}

Keywords: microhabitat, terrestrial passerines, vegetation heterogeneity, Atlantic forest, southern Brazil.

\section{RESUMO}

\section{Passeriformes de solo em um fragmento de floresta Atlântica no Sul do Brasil}

Os microhábitats de quatro passeriformes de solo foram estudados no Parque Estadual Mata dos Godoy, um fragmento de floresta Atlântica no Sul do Brasil. Grallaria varia e Hylopezus nattereri apresentaram baixa abundância e ocorrência em apenas uma área do PG, enquanto Chamaeza campanisona e Corythopis delalandi foram registrados nas duas áreas. Os microhábitats de C. campanisona, G. varia e H. nattereri apresentaram muitas árvores de grande porte e um estrato inferior denso. $\mathrm{O}$ microhábitat de $C$. delalandi apresentou poucas árvores de grande porte.

Palavras-chave: microhábitat, passeriformes de solo, vegetação heterogênea, floresta Atlântica, sul do Brasil.

\section{INTRODUCTION}

Species distribution and diversity in tropical forests can be explained through such factors as abiotic conditions, vegetation complexity, and biological characteristics of each species (Holmes et al., 1979; Blondel, 1985). Some terrestrial passerines (e.g., Grallaria sp, Hylopezus sp) are highly selective regarding microhabitat, have large territories and low mobility, and avoid secondgrowth forest, which makes them very sensitive to forest fragmentation (Bierregaard \& Lovejoy,
1989; Stouffer \& Bierregaard, 1995; Canaday, 1997; Stratford \& Stouffer, 1999; Renjifo, 1999).

Microhabitats can be defined as occupied areas presenting specific environmental features that meet the biological needs of given species (Karr, 1990; Stotz et al., 1996). Distribution and abundance of bird species in tropical forest are strongly related to occurrence of their typical microhabitats (e.g. Kratter, 1997; Sodhi et al., 1999; Illera, 2001; Bonaccorso \& Barreto, 2002).

This paper describes microhabitats of four terrestrial passerines and evaluates their relative 
abundance and distribution in an Atlantic forest remnant of southern Brazil.

\section{METHODS}

The study was conducted at Mata dos Godoy State Park (PG; $23^{\circ} 27^{\prime} \mathrm{S}, 51^{\circ} 14^{\prime} \mathrm{W}$; Fig. 1), located $15 \mathrm{~km}$ south of Londrina, Paraná state, located in southern Brazil. The northern PG area (NP) (600-610 m asl), is fairly level. The southern PG area (SP) slopes downwards $(600-480 \mathrm{~m})$ to the Apertados river. Silveira (1993) and Bianchini et al. (2001) pointed out that that the NP vegetation structure is differs substantially from that of the SP. A dense canopy covers the NP, in which the most abundant tree species are Cabralea canjerana (Meliaceae), Euterpe edulis (Areceae), Ocotea indecora (Lauraceae), and Nectandra megapotamica (Lauraceae), with but few emergent trees, such as Aspidosperma polyneuron (Apocynaceae) and Sloanea monosperma (Elaeocarpaceae). Due to the dense upper canopy, the subcanopy receives lower light levels while the understory, which is relatively open, presents short trees and bushes, e.g., such as Eugenia verrucosa (Myrtaceae), Sorocea bonplandii (Moraceae), Miconia tritis (Melastomataceae) and Piper sp (Piperaceae). An abandoned path ( $2 \mathrm{~m}$ wide) running through a slightly deforested area leads to the NP entrance.

In contrast, the SP canopy foliage is not dense, and the trees Chrysophyllum gonocarpum (Sapotaceae), Campomanesia xanthocarpha (Myrtaceae), and Parapiptadenia rigida (Fabaceae) are common. Emergent trees are rare, perhaps because of frequent tree falls on the steep slopes. Gaps (where Chusquea sp [Poaceae] and Celtis iguanaea [Ulmaceae] are quite abundant) are much more common in SP than they are in NP. Even outside the gaps, the SP sub-canopy, which exceeds in density that of the NP, shows high abundance of Nectandra megapotamica (Lauraceae), Alseis floribunda (Rubiaceae), Matayba elaeagnoides (Sapindaceae), Lonchocarpus muehlbergianus

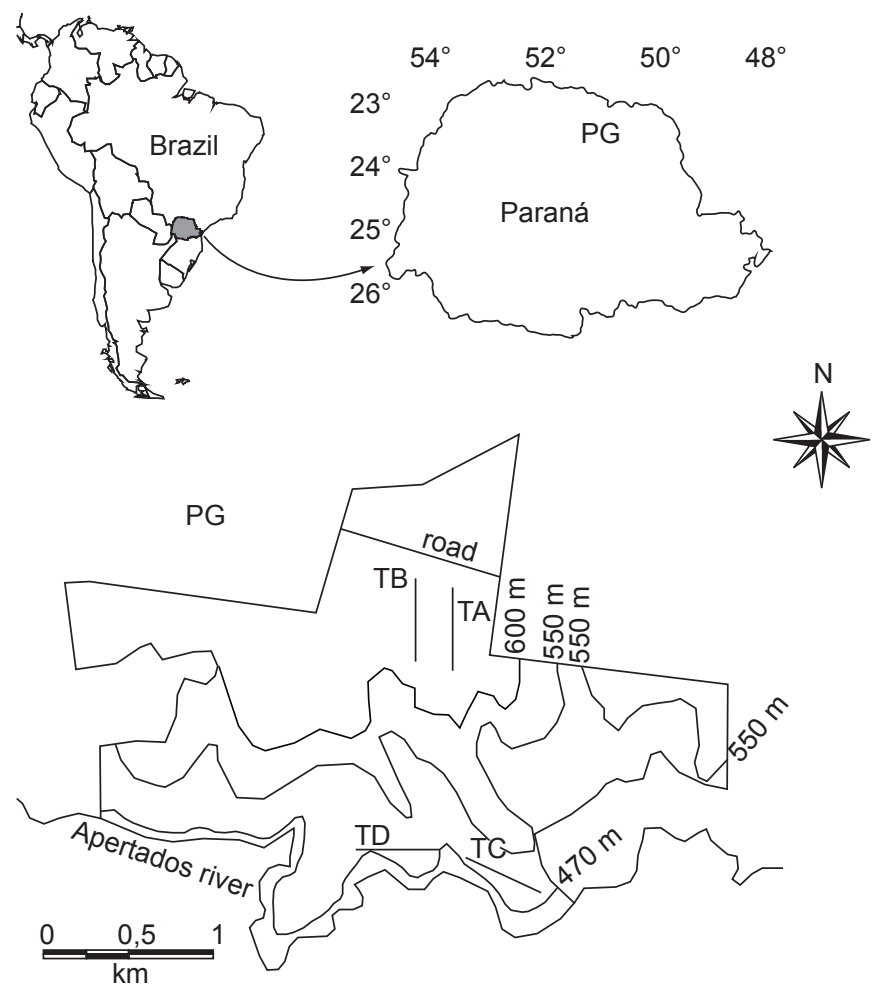

Fig. 1 - Location of Mata dos Godoy State Park (PG) and the four transects: TA and TB (northern area), and TC and TD (southern area). 
(Fabaceae), Eugenia verrucosa (Myrtaceae), and Trichilia cassareti (Meliaceae). Running along the Apertados river is a $50-100 \mathrm{~m}$ wide floodplain, which overflows (usually from November to February) for short periods.

The method of point counts and unlimited distance (Blondel et al., 1970) was used to measure abundance of terrestrial passerines in SeptemberDecember 2001 (only one observer, L. dos Anjos, employed this method in the field). Two $0.5 \mathrm{~km}$ transects were drawn (TA and TB) $300 \mathrm{~m}$ apart in $\mathrm{NP}$, and two others in SP (TC and TD), each of which were located $100 \mathrm{~m}$ from the river (Fig. 1). In each transect, five points were determined, $100 \mathrm{~m}$ apart and sequentially numbered (1 to 5). Each transect was sampled monthly; 40 point counts were performed in each PG area during four months. The sampling point sequence was always the same $(1,3,5,2,4)$. Sampling began at dawn at the first point, and finished about $3 \mathrm{~h}$ later at the last point (num. 4). Sampling required $20 \mathrm{~min}$ at each point, with a 15 min break between sampling points. Vocalization of each species was considered as one contact. Relative abundance of terrestrial passerines at the NP and SP was expressed by an index of point abundance (IPA), which is the total number of contacts of each species divided by the total number of points sampled (40). Differences in species abundances between the two sites were tested for significance by using Chi-square tests. To avoid counting the same individual or group more than once, a standard form was used to order to locate and map the counted individuals.

Microhabitat sampling, conducted from October 2001 to October 2002, consisted of measuring nine variables on $10 \mathrm{~m}$ radius circularplots (0.031 ha) along the same transects used for point counts. Intensive searches were made in each PG area; $264 \mathrm{~h}$ field observations were made in NP, and $312 \mathrm{~h}$ in SP. Once detected (aurally or visually), a terrestrial passerine individual's location was considered the circularplot center point and represented one sample of the microhabitat. For each circular plot, the following variables were recorded: 1) leaf litter; 2) ferns; 3) bamboo thickets; 4) shrubs (woody-stemmed $<1 \mathrm{~m}$ in height); 5) herbs; 6) gaps; 7) tangles on the ground; 8) small trees with $5 \mathrm{~cm}$ diameter-atbreast-height (dbh); and 9) large trees with above $30 \mathrm{~cm} \mathrm{dbh}$. Each variable was measured using a semi-quantitative scale $(0,1$, and 2$)$. All variables excepting the last were rated as follows: 0) absent; 1) vegetation variable occupied $10 \%$ of the circular plot; 2) vegetation variable occupied more than $10 \%$ of the circular plot. For large trees, ratings on the semi-quantitative scale were three: 0 ) absence of large trees; 1) presence of up to three large trees in the circular plot; 2) more than three large trees in the circular plot.

Principal component analysis (PCA) was used to determine relationships between vegetation variables, which in turn yielded useful descriptors of the terrestrial passerine microhabitats.

\section{RESULTS}

Four terrestrial passerines were recorded in PG: Chamaeza campanisona, Grallaria varia, Hylopezus nattereri (all three Formicariidae), and Corythopis delalandi (Tyrannidae). Only C. campanisona was recorded in both areas during the point-count sampling period, being more abundant in SP (IPA $=0.275$ ) than in NP $($ IPA $=0.125)$; however, the difference was not significant $\left(\chi_{1}^{2}=2.25 ; \quad P=0.13\right)$. Grallaria varia $(\mathrm{IPA}=0.100)$ was recorded only in NP, while $H$. nattereri $(\mathrm{IPA}=0.125$ ) and $C$. delalandi $($ IPA $=0.175)$ were recorded only in SP (Table 1).

The data from species records in the two PG areas during microhabitat sampling were similar to results from the point-count samples, except for C. delalandi, which was also recorded in NP. Chamaeza campanisona was present in 34 samples, G. varia in 9 samples, $H$. nattereri in 10 samples, and $C$. delalandi in 37 samples (Table 2).

The combination of all microhabitat samples of birds species (90; Table 2) is shown in Fig. 2. The first two principal components explained $61.5 \%$ of the variation (eigenvalues axis $1=4.40$; eigenvalues axis $2=1.15$ ). Principal-component one (PC1) explained $48.7 \%$ of the variation, with high positive loadings for leaf litter $(\mathrm{PC} 1=+0.86)$, ferns $(\mathrm{PC} 1=+0.81)$, bushes ( $\mathrm{PC} 1=+0.73)$, herbs $(\mathrm{PC} 1=+0.86)$, tangles $(\mathrm{PC} 1=+0.70)$, and large trees $(\mathrm{PC} 1=+0.71)$. Principal- component two (PC2) explained $12.7 \%$, with high positive loadings for bamboo thickets $(\mathrm{PC} 2=+0.59)$ and gaps $(\mathrm{PC} 2=+0.70)$. The variables derived from the PCA indicate that the microhabitats of $C$. campanisona, $G$. varia, and were similar and characterized 
TABLE 1

Contact numbers, relative abundance (IPA) of the four terrestrial passerines in the northern (NP) and southern (SP) areas of the Mata dos Godoy State Park.

\begin{tabular}{|l|c|c|c|c|}
\hline \multirow{2}{*}{ Terrestrial Passerines } & \multicolumn{2}{c|}{ Number of contacts } & \multicolumn{2}{c|}{ Relative abundance } \\
\cline { 2 - 5 } & NP & SP & NP & SP \\
\hline Chamaeza campanisona & 5 & 11 & 0.125 & 0.275 \\
\hline Grallaria varia & 4 & 0 & 0.100 & 0 \\
\hline Hylopezus nattereri & 0 & 5 & 0 & 0.125 \\
\hline Corythopis delalandi & 0 & 7 & 0 & 0.175 \\
\hline
\end{tabular}

TABLE 2

Number of microhabitat samples of the four terrestrial passerines in the northern (NP) and southern (SP) areas of the Mata dos Godoy State Park.

\begin{tabular}{|l|c|c|}
\hline \multirow{2}{*}{ Terrestrial Passerines } & \multicolumn{2}{|c|}{ Number of microhabitat samples } \\
\cline { 2 - 3 } & NP & SP \\
\hline Chamaeza campanisona & 14 & 20 \\
\hline Grallaria varia & 10 & 0 \\
\hline Hylopezus nattereri & 0 & 9 \\
\hline Corythopis delalandi & 13 & 24 \\
\hline
\end{tabular}

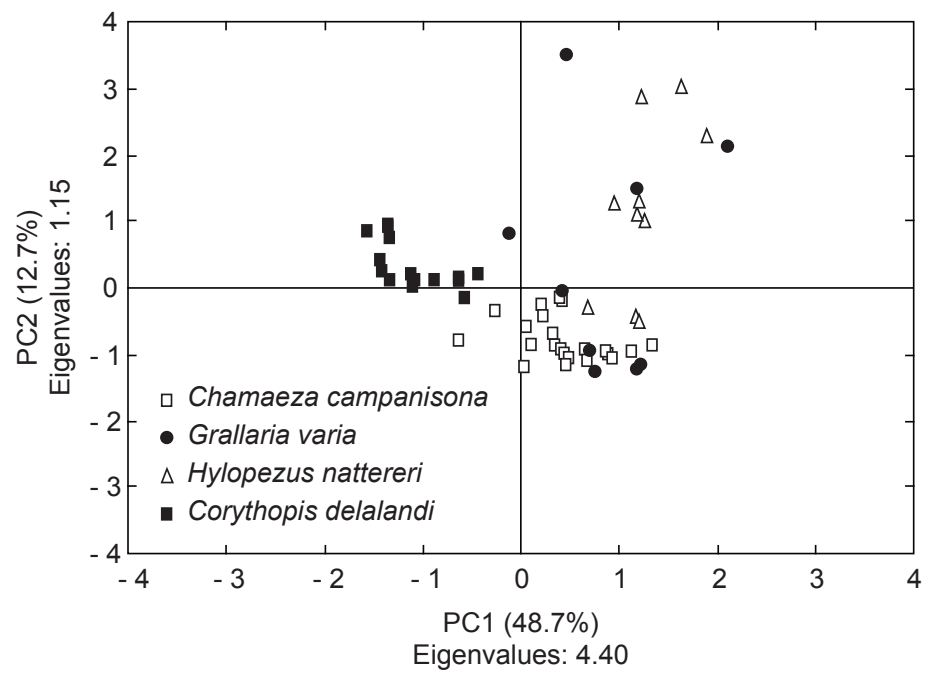

Fig. 2 - Mean principal component (PC) values for the two PCs used in microhabitat characterization of the four terrestrial Passerines.

by abundance of larger trees and heterogeneous understory with ferns, bushes, herbs, tangles, and leaf litter, and, in the case of $H$. nattereri, also influenced by the presence of bamboo thickets and gaps. C. delalandi microhabitat was characterized by lower abundance of these variables.

\section{DISCUSSION}

The most significant variable derived from the PCA of the Formicariidae species microhabitat was abundance of large trees with consequently lower light levels in the subcanopy and understory, the latter of which is relatively open, with no type 
of vegetation dominant. This microhabitat provides both foraging and nesting sites (Cody, 1981; Willson \& Comet, 1996), especially for terrestrial passerines that walk on the forest floor and catch prey from the ground (Willis, 1992; Ridgely \& Tudor, 1994). Besides abundance of large trees, gaps and bamboo thickets also characterize the $H$. nattereri microhabitat, which closely fits the habitat descriptions of Whitney et al. (1995) and Stotz et al. (1996). In contrast, the $C$. delalandi microhabitat was characterized by lower large-tree abundance and low-density understory, a result closely fitting microhabitat descriptions of Ridgely \& Tudor (1994), who noted that $C$. delalandi tolerates disturbed environments and is frequently found in small fragments, the latter observation also having being made by Burke \& Nol (1998). In addition, $C$. delalandi has also been found in river-edge habitats (Silveira, 1993; Bianchini et al., 2001).

Comparisons of the microhabitat and vegetation described by Silveira (1993) and by Bianchini et al. (2001) suggest that restricted distribution and low abundance of G. varia and $H$. nattereri can be related to specific vegetation characteristics (Holmes et al., 1979; Cody, 1981; Sodhi et al., 1999). In the present study, Grallaria varia was registered only in the northwestern area of PG, next to transect TB and the abandoned road. A dense canopy plus an open and shady understory occurs in this area, as previously observed by Silveira (1993) and Bianchini et al. (2001), and the large eyes of Grallaria varia suggest adaptation to shady sites (Sick, 1997). Furthermore, small pools of water are found next to the abandoned road, mainly during the rainy season, and this species has a habit of bathing in forest pools (Sick, 1997), as well as foraging inside forest edges (Ridgely \& Tudor, 1994). It was observed doing both along the margins of the abandoned road.

Hylopezus nattereri was strongly influenced by occurrence of bamboo thickets, found only in SP. This steep-sloped area presents tree falls and natural gaps (Silveira, 1993; Bianchini et al., 2001), which give rise to bamboo-thicket development (Tabarelli \& Mantovani, 1999).

Small, disturbed forest fragments are characterized by structural vegetation changes, usually along their edges. Gaps increase in these areas, providing good conditions for higher abundance of light-dependent plant species, such as bamboo (Tabarelli et al., 1999). This would suggest that $H$. nattereri could be present in disturbed environments in which bamboo is a common colonizer. However, Stotz et al. (1996) stated that despite occurrence of $H$. nattereri in bamboo microhabitats, this species is highly sensitive to disturbed environments, confirmed by its absence in our observations in disturbed areas having bamboo (Anjos et al., 2004).

Since terrestrial birds (e.g., G. varia and $H$. nattereri) are specialized for certain environments, they are more sensitive to habitat fragmentation (Stouffer \& Bierregaard, 1995; Stotz et al., 1996; Stratford \& Stouffer, 1999; Renjifo, 1999), and thus restricted to areas where their microhabitats occur. Göerck (1997) used geographic distribution, habitat specificity, and population size as parameters to determine vulnerability degrees for Atlantic forest birds. By this index, G. varia and $H$. nattereri in PG can be classified as rare, by reason of their low abundance and microhabitat specificity. Atlantic forest fragmentation in northern Paraná has resulted in several forest remnants, only a few of which have similar vegetation characteristics to those of PG, which suggests why G. varia and $H$. nattereri are also rare in these areas and may be quite vulnerable to extinction, as a result of microhabitat loss in northern Paraná.

The SP of PG is characterized by higher leaf litter abundance, diversity and abundance of deciduous tree species, and higher humidity through its proximity to the Apertados river (Bianchini et al., 2001). These features benefit terrestrial invertebrates by ensuring prey availability (Petit \& Petit, 1996; Robinson, 1998; Burke \& Nol, 1998; Anjos, 2002), which in turn could be implicated in the high abundance of $C$. campanisona in SP. Prothonotary Warblers (Protonotaria citrea) is another songbird that, according to Petit \& Petit (1996), selects humid habitats because they offer high arthropod abundance.

In addition to what was registered in the point count data, $C$. delalandi was also registered in NP along the abandoned road in the one of its microhabitats. Other factors, such as interspecific or intraspecific competition, could induce some individuals to colonize slightly different microhabitats. Another biological explanation could be annual variation. But it is also possible that by using the point count method this species was simply overlooked in that PG area. 
In short, the results indicate that terrestrial passerines in $\mathrm{PG}$ show different relationships between their microhabitats, on one hand, and distribution and abundance on the other. In Grallaria varia and $H$. nattereri, distribution and abundance were based on specific microhabitat characteristics. Both C. campanisona and $C$. delalandi were recorded in the two PG areas, suggesting that these species are more generalized. Furthermore, their microhabitats also presented different features, as shown in Fig. 2.

Acknowledgments - For financial support, we thank the Conselho Nacional de Pesquisa (CNPq) - International CooperaçãoPrograma Mata Atlântica (690146/01-9), and Londrina State University. The Instituto Ambiental do Paraná (IAP) gave permission for field study in Mata dos Godoy State Park. L. dos Anjos thanks the CNPq for research grants (350054/95-9). J. Göerck, O. A. Shibatta, M. Marini, M. A. A. Santos, M. A. Pizo, P. Develey, and an anonymous referee made important suggestions that substantially improved the final version of this manuscript.

\section{REFERENCES}

ANJOS, L., 2002, Forest bird communities in the Tibagi river hydrographic basin, southern Brazil. Ecotropica, 8: 67-79.

ANJOS, L., ZANETTE, L. \& LOPES, E. V., 2004, Effects of fragmentation on the bird guilds of the Atlantic Forest in north Paraná, Southern Brazil. Orn. Neotrop., 15(suppl.): 137-144.

BIANCHINI, E., PIMENTA, J. A., \& SANTOS, F. A. M. dos, 2001, Spatial and temporal variation in the canopy cover in a tropical semi-deciduous forest. Brazilian Archives of Biology and Technology, 44: 269-276.

BIERREGAARD, R. O. JR. \& LOVEJOY, T. E., 1989, Effects of forest fragmentation on Amazonian understory bird communities. Acta Amazônica, 19: 215-241.

BLONDEL, D., FERRY, C., \& FROCHOT, B., 1970, La méthode des indices ponctuels d'abondance (I.P.A.) ou des relevés d'avifaune par "stations d'écoute". Alauda, 38: 55-71.

BLONDEL, J., 1985, Habitat selection in island versus mainland birds, pp. 477-517. In: M. L. Cody (ed.), Habitat selection in birds. Academic Press, San Diego, USA.

BONACCORSO, E. \& BARRETO, G. R., 2002, Microhabitat use by foraging Venezuelan Wood-Quails (Odontophorus columbianus). J. Field Ornithol., 73: 318-322.

BURKE, D. M. \& NOL, E., 1998, Influence of food abundance, nest-site habitat, and forest fragmentation on breeding Ovenbirds. Auk, 115: 96-104.

CANADAY, C., 1997, Loss of insectivorous birds along a gradient of human impact in Amazonia. Biol. Conserv., 77: 63-77.

CODY, M. L., 1981, Habitat selection in birds: The roles of vegetation structure, competitors, and productivity. Bioscience, 31: 107-113.

GÖERCK, J. M., 1997, Patterns of rarity in birds of the Atlantic forest of Brazil. Conserv. Biol., 11: 112-118.
HOLMES, R. T., BONNEY, R. E. JR., \& PACALA, W., 1979, Guild structure of the Hubbard Brook bird community: a multivariate approach. Ecology, 60: 512-520.

ILLERA, J. C., 2001, Habitat selection by Canary Islands stonechat (Saxicola dacotidae)(Meade-Waldo, 1889) in Fuerteventura Island: a two-tier habitat approach with implications for its conservation. Biol. Conserv., 97: 339-345.

KARR, J. R., 1990, Interactions between forest birds and their habitats: A comparative synthesis, pp. 379-386. In: A. Keast (ed.), Biogeography and ecology of forest bird communities. SPB Academic Publishing, The Hague.

KRATTER, A. W., 1997, Bamboo specialization by Amazonian birds. Biotropica, 29: 100-110.

PETIT, L. J. \& PETIT, D. R., 1996, Factors governing habitat selection by prothonotary warblers: field test of the Fretwell-Lucas model. Ecol. Monogr., 66: 367-387.

RENJIFO, L. M., 1999, Composition changes in a subandean avifauna after long-term forest fragmentation. Conserv. Biol., 13: 1124-1139.

RIDGELY, R. S. \& TUDOR, G., 1994, The birds of South America: the suboscine passerines. University of Texas Press, Austin, USA.

ROBINSON, S. K., 1998, Another threat posed by forest fragmentation: reduced food supply. Auk, 115: 1-3.

SICK, H., 1997, Ornitologia brasileira. Nova Fronteira, Rio de Janeiro, Brasil.

SILVEIRA, M., 1993, Estrutura vegetacional em uma topossequência no Parque Estadual "Mata dos Godoy", Londrina, PR. Dissertação de Mestrado. Universidade Federal do Paraná, Curitiba, Brasil.

SODHI, N. S., PASZKOWSKI, C. A., \& KEEHN, S., 1999, Scale-dependent habitat selection by American Redstarts in aspen-dominated forest fragments. Wilson Bull., 111: 70-75.

STOTZ, D. F., FITZPATRICK, J. W., PARKER III, T., \& MOSKOVITS, D. K., 1996, Neotropical Birds: Ecology and Conservation. University of Chicago Press, Chicago, USA.

STOUFFER, P. C. \& BIERREGAARD, R. O. JR., 1995, Use of Amazonian forest fragments by understory insectivorous birds. Ecology, 76: 2429-2445.

STRATFORD, J. A. \& STOUFFER, P. C., 1999, Local extinction of terrestrial insectivorous birds in a fragmented landscape near Manaus, Brazil. Conserv. Biol., 13: 1416-1423.

TABARELLI, M., MANTOVANI, W., \& PERES, C. A., 1999, Effects of habitat fragmentation on plant guild structure in the montane Atlantic forest of southeastern Brazil. Biol. Conserv., 91: 119-127.

TABARELLI, M. \& MANTOVANI, W., 1999, Clareiras naturais e a riqueza de espécies pioneiras em uma floresta Atlântica Montana. Rev. Brasil. Biol., 59: 251-261.

WILLIS, E. O., 1992, Three Chamaeza antthrushes in eastern Brazil (Formicariidae). Condor, 94: 110-116.

WILLSON, M. F. \& COMET, T. A., 1996, Bird communities of northern forest: Ecological correlations of diversity and abundance in the understory. Condor, 98: 350-362.

WHITNEY, B. M., PACHECO, J. F., ISLER, P. R., \& ISLER, M. L., 1995, Hylopezus nattereri (Pinto, 1937) is a valid species (Passeriformes: Formicariidae). Ararajuba, 3: 37-42. 